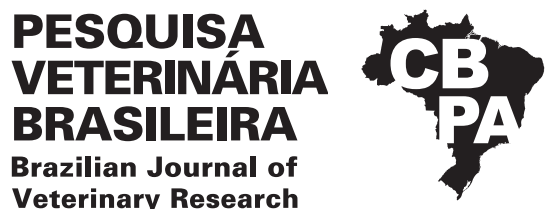

\title{
Prevalence of canine atopic dermatitis at the Veterinary Hospital of the "Universidade Federal Rural da Amazônia” in Belém/Pará, Brazil ${ }^{1}$
}

\author{
Giselle A. Couceiro ${ }^{2 *}$ (D), Siane Marina M. Ribeiro², Mariana M. Monteiro ${ }^{3}$, \\ Andre Marcelo C. Meneses ${ }^{4}$, Sinerey Karla S.A. Sousa ${ }^{5}$ and Leandro N. Coutinho ${ }^{4}$
}

\begin{abstract}
Couceiro G.A., Ribeiro S.M.M., Monteiro M.M., Meneses A.M.C., Sousa S.K.S.A. \& Coutinho L.N. 2021. Prevalence of canine atopic dermatitis at the Veterinary Hospital of the "Universidade Federal Rural da Amazônia" in Belém/Pará, Brazil. Pesquisa Veterinária Brasileira 41:06778, 2021. Graduate Program in Health and Animal Production in the Amazon, Universidade Federal Rural da Amazônia, Avenida Perimetral 2501, Terra Firme, Belém, PA 66077-830, Brazil. E-mail: gisellecouceiro@gmail.com

Canine atopic dermatitis (CAD) is a pruritic, chronic inflammatory disease, recurrent and genetically predisposed, which is the second most frequent allergic skin disorder, and ranks second among all the causes of pruritus in dogs worldwide. Given the absence of data on the occurrence of CAD in the northern region of Brazil, the aim of the current study was to conduct a survey to define the prevalence of canine atopic dermatitis attended at the Dermatology Department of the Mário Dias Teixeira Veterinary Hospital of the "Universidade Federal Rural da Amazônia" (HOVET-UFRA). To determine the prevalence of CAD, a retrospective survey was carried out of clinical records and results of dermatological examinations conducted at the Dermatology Department of HOVET-UFRA Belém, Pará from October 2018 to October 2019. During this period, 456 dogs were examined, of which $25.65 \%$ (117) were diagnosed with atopic dermatitis. Among the animals diagnosed, 62.4\% (73) were females and 51.7\% (29) were of the Shih-tzu breed. This level of atopic dermatitis is considered high. There are still no exact data on the incidence and prevalence of this dermatopathy, with described occurrence ranging from 3 to $15 \%$ of the canine population, a geographical relationship may be present. Although a sex-related predisposition has not been proven, a higher incidence of atopy in females is described, which indicated this may be the case. The most commonly diagnosed dogs in this study were the Shih-tzu breed. It is suspected that the regional popularity of some breeds, or the different genetic backgrounds in different geographical areas, may affect the predominance of CAD in some breeds. The results of the present study demonstrate the need for more research on the prevalence of canine atopic dermatitis, and better means of characterizing the population of atopic dogs in the region, so that it is possible to obtain a reliable epidemiological profile.
\end{abstract}

INDEX TERMS: Atopic dermatitis, prevalence, dermatopathy, Pará, Brazil, dogs.

\footnotetext{
${ }^{1}$ Received on September 14, 2020.

Accepted for publication on October 20, 2020.

${ }^{2}$ Graduate Program in Health and Animal Production in the Amazon, Universidade Federal Rural da Amazônia (UFRA), Avenida Perimetral 2501, Terra Firme, Belém, PA 66077-530, Brazil. *Corresponding author: gisellecouceiro@gmail.com

${ }^{3}$ Escola Superior da Amazônia (ESAMAZ), Rua Municipalidade 546, Reduto, Belém, PA 66053-180, Brazil.

${ }^{4}$ Instituto de Saúde e Produção Animal, Universidade Federal Rural da Amazônia, (UFRA), Avenida Perimetral 2501, Terra Firme, Belém, PA 66077-530, Brazil.

${ }^{5}$ Hospital Veterinário Mário Dias Teixeira, Universidade Federal Rural da Amazônia (UFRA), Via Felisberto Camargo, Avenida Perimetral 2501, Terra Firme, Belém, PA 66077-530, Brazil.
}

RESUMO.- [Prevalência de dermatite atópica canina no Hospital Veterinário da Universidade Federal Rural da Amazônia em Belém/Pará, Brasil.] A dermatite atópica canina (DAC) é uma doença inflamatória crônica e pruriginosa recorrente e geneticamente predisposta, que se destaca como o segundo transtorno cutâneo alérgico mais frequente e ocupa o segundo lugar entre todas as causas de prurido em cães. Diante da ausência de dados da ocorrência de DAC na região Norte do Brasil, objetivou-se realizar um levantamento de dados para definir a prevalência de dermatite atópica canina atendida no Serviço de Dermatologia do Hospital Veterinário Mário Dias Teixeira da Universidade Federal Rural da Amazônia 
(HOVET-UFRA). Foi realizado um levantamento retrospectivo através dos registros clínicos e dos resultados de exames dermatológicos com base nos atendimentos dermatológicos no setor de Dermatologia do HOVET-UFRA Belém/Pará, de outubro de 2018 a outubro de 2019 para determinar a prevalência de DAC. Nesse período, foram atendidos 456 cães e destes, $25,65 \%$ (117) foram diagnosticados com dermatite atópica. Dentre os animais diagnosticados, 62,4\% (73) eram fêmeas e 51,7\% (29) eram da raça Shih-tzu. Neste estudo houve uma alta prevalência de cães com Dermatite atópica. Ainda não existem dados exatos sobre a incidência e a prevalência desta dermatopatia, com ocorrência descrita variando de 3 a 15\% da população canina, podendo ter relação geográfica. Embora a predisposição sexual não tenha sido comprovada, descrevese maior incidência de atopia em fêmeas, concordando com esta pesquisa. Os cães mais acometidos neste estudo foram da raça Shih-tzu. Suspeita-se que a popularidade regional de algumas raças ou os diferentes antecedentes genéticos em diferentes áreas geográficas afetam a predominância de algumas raças. Estes resultados mostraram que a prevalência de DAC em cães é a mais frequentemente diagnosticada no setor de Dermatologia do HOVET-UFRA, sendo mais prevalente em fêmeas e na raça Shih-tzu, podendo refletir um aspecto regional desta dermatopatia. Os resultados do presente estudo contribuíram para demonstrar a importância de mais pesquisas sobre a prevalência da Dermatite atópica canina e melhor caracterizar a população de cães atópicos na região, para que seja possível obter um perfil epidemiológico confiável.

TERMOS DE INDEXAÇÃO: Dermatite atópica, prevalência, dermatopatia, Pará, Brasil, caninos.

\section{INTRODUCTION}

Veterinary dermatology is commonly attended in small animal clinics. Canine atopic dermatitis (CAD) is the second most frequently diagnosed allergic skin disorder and also ranks second among causes of pruritus in dogs worldwide (Zanon et al. 2008, Scott et al. 2013). CAD is a pruritic, chronic and inflammatory disease (Gonzalez et al. 2016), recurrent and genetically predisposed (Hensel et al. 2015).

The study of dermatopathies is important for small animal clinicians and dermatopathologists because, although the literature on canine dermatology is vast, there is little information available on the occurrence of the main skin diseases by geographical region globally (Sischo et al. 1989, Scott \& Paradis 1990, Hill et al. 2006).

Given the absence of CAD occurrence data for the northern region of Brazil, the objective of the current study was to conduct a survey to define the prevalence of canine atopic dermatitis in animals seed at the Dermatology Department of the Mário Dias Teixeira Veterinary Hospital of the "Universidade Federal Rural da Amazônia” (HOVET-UFRA).

\section{MATERIALS AND METHODS}

To determine the prevalence of canine atopic dermatitis (CAD), a retrospective survey of the clinical records of the AMZ SISVET, focused on dermatological care, was carried out at the Dermatology Department of the Mário Dias Teixeira Veterinary Hospital of the "Universidade Federal Rural da
Amazônia”, Belém/Pará, across the 13 months from October 2018 to October 2019.

Inclusion criteria were the presence CAD of diagnosis on the chart, and the absence of dermatological comorbidities. The animals in the system had been submitted to standard procedures: anamnesis, clinical examination and dermatological laboratory examinations the latter comprised of evaluation with a wood's lamp, collection of skin samples with acetate tape for parasitological and samples for cytological analysis and for fungal hair culture, with the objective of discarding dermatopathies associated to CAD and non-CAD dermatopathies. These include those diagnosed as having CAD.

To obtain data on CAD prevalence, only veterinary records with CAD-positive assessments were considered. To analyze the data, descriptive statistics were complimented with qualitative analysis of presence or absence of dermatopathy, sex, and breed of CAD-infested dogs with Chi-square Tests.

\section{RESULTS}

During the period from October 2018 to October 2019, 456 dogs were examined at the Dermatology department of the Mário Dias Teixeira Veterinary Hospital of the "Universidade Federal Rural da Amazônia", Belém, Pará. Of these 117 (25.65\%) were diagnosed with atopic dermatitis, making this the most commonly examined dermatopathy during the study period. In terms of sex, 44 (37.6\%) were male and $73(62.4 \%)$ were female $(p=0.0073)$, regardless of age.

CAD was predominant in dogs mixed breed, but among all those attended with dermatopathies in general (total of 456 dogs), the most prevalent breed was the Shih-tzu with 15 animals (51.7\%) with CAD among the 29 attended followed by Poodle with 15 (28.3\%) animals with CAD among the 53 attended and mixed breed with 56 (24.3\%) animals with CAD among the 230 attended (Table 1 ).

The most affected breeds among the 117 animals diagnosed with CAD in this study were: mixed breed $(47.9 \%, n=56)$, Shih-tzu (12.8\%, n=15), Poodle (12.8\%, n=15), Maltese $(4.3 \%$, $n=5)$, Pitbull (2.6\%, n=3), Beagle (2.6\%, $n=3)$, Sharpei $(2.6 \%$, $n=3)$, Lhasa apso $(2.6 \%, n=3)$, Labrador retriever $(1.7 \%, n=2)$, Yorkshire terrier (1.7\%, n=2), Pug (1.7\%, n=2), Dachshund $(1.7 \%, \mathrm{n}=2)$, Golden retriever $(1.7 \%, \mathrm{n}=2)$, German shepherd $(0.9 \%, n=1)$, Border collie $(0.9 \%, n=1)$, American Staffordshire terrier $(0.9 \%, n=1)$ and Schnauzer $(0.9 \%, n=1)$ (Table 2).

\section{DISCUSSION}

According to the International Task Force for CAD, exact data on the incidence and prevalence of this dermatopathy globally are not yet available (Hillier \& Griffin 2001). The described occurrence is broad, ranging from 3 to $15 \%$ of the

Table 1. Breed prevalence of canine atopic dermatitis at the Veterinary Hospital of "Universidade Federal Rural da Amazônia", in Belém/PA, Brazil, from October 2018 to October 2019 between specific breeds attended with general dermatopathies

\begin{tabular}{lcc}
\hline \multicolumn{1}{c}{ Breed } & Frequency & $\%$ \\
\hline Shih-Tzu & $15 / 29$ & 51.7 \\
Poodle & $15 / 53$ & 28.3 \\
Mixed breed & $56 / 230$ & 24.3
\end{tabular}


dog population, although the actual prevalence and incidence are not known (Jaeger et al. 2010).

The percentage of $25.65 \%$ for atopic dermatitis found in this study was lower than that published by Souza et al. (2009), in which it represented $44.21 \%$ in dogs in the municipality of Santa Maria, Rio Grande do Sul state, Brazil. Amarante et al. (2015) evaluating clinical records of 2,280 dogs examined by the Dermatology Sector of the Small Animal Hospital of the "Universidade Federal Rural do Rio de Janeiro", from 2005 to 2010 , reported that atopic dermatitis was diagnosed in $36.1 \%$ of the studied canines attended. In contrast, though also in southern Brazil, Machado et al. (2004) reported lower prevalence (12.8\%). Even lower results were found by (Cardoso et al. 2011) in a survey at the Archive Service of the Veterinary Hospital, "Universidade Estadual do Norte do Paraná", from February 2003 to December 2006, with a prevalence of 3.9\%, a result that is also lower than the current study. Such differences in prevalence may have a geographical relationship, especially climate.

Neither Medeiros (2017) nor Bizikova et al. (2015) reported any sexual predisposition in CAD. However, in the current study a considerable preponderance of females (62.4\%) was recorded, corroborating the studies of (Neto 2012), where CAD was more frequent in females (62.4\%) than in males (37.6\%) (Cardoso et al. 2011), where 6 affected animals were female and 4 were male, and Vandresen (2014) with $79 \%$ of females affected. Thus, it appears that females are more affected by dermatopathy in the vast majority of published studies.

Table 2. Sexual and breed prevalence of canine atopic dermatitis at the Veterinary Hospital of "Universidade Federal Rural da Amazônia", in Belém/PA, Brazil, from October 2018 to October 2019

\begin{tabular}{|c|c|c|c|c|}
\hline Dermatopathy & Gender & Breed & Frequency & $\%$ \\
\hline \multirow{20}{*}{$\begin{array}{l}\text { Atopic } \\
\text { dermatitis }^{\text {a }}\end{array}$} & & & $117 / 456$ & 25.65 \\
\hline & Female $^{\mathrm{b}}$ & & $73 / 117$ & 62.4 \\
\hline & Male & & $44 / 117$ & 37.6 \\
\hline & & Mixed breed & $56 / 117$ & 47.9 \\
\hline & & Shih-Tzu & $15 / 117$ & 12.8 \\
\hline & & Poodle & $15 / 117$ & 12.8 \\
\hline & & Maltese & $5 / 117$ & 4.3 \\
\hline & & Pitbull & $3 / 117$ & 2.6 \\
\hline & & Beagle & $3 / 117$ & 2.6 \\
\hline & & Sharpei & $3 / 117$ & 2.6 \\
\hline & & Lhasa apso & $3 / 117$ & 2.6 \\
\hline & & Labrador retriever & $2 / 117$ & 1.7 \\
\hline & & Yorkshire Terrier & $2 / 117$ & 1.7 \\
\hline & & Pug & $2 / 117$ & 1.7 \\
\hline & & Dachshund & $2 / 117$ & 1.7 \\
\hline & & Golden Retriever & $2 / 117$ & 1.7 \\
\hline & & German Shepherd & $1 / 117$ & 0.9 \\
\hline & & Border Collie & $1 / 117$ & 0.9 \\
\hline & & $\begin{array}{c}\text { American } \\
\text { Starffordshire Terrier }\end{array}$ & $1 / 117$ & 0.9 \\
\hline & & Schnauzer & $1 / 117$ & 0.9 \\
\hline
\end{tabular}

adherence.
Barboza et al. (2001) in the city of Zulia, Venezuela, found that mixed breed dogs were more affected by atopic dermatitis than any other breed, which agrees with the studies of Borracini et al. (2018) in Rosario, Argentina. The current trend for increased action by nongovernmental animal protection organizations to diminish of the number of street dogs, so increasing levels of adoption, is very likely to have contributed to the growth of mixed breed animals whose carers have subsequently accessed the atopic dermatitis diagnosis, the records of which form the basis of this work, as in the work of (Alves et al. 2018).

Marcelo (2005) and Beteta (2016), report on surveys of three different districts of Lima, Peru (Miraflores, Magdalena del Mar and San Borja) that found that the breed with the highest incidence of canine atopic dermatitis was mixed breed, while a study that included 843 atopic dogs found similar results (Favrot et al. 2010); although two breed-specific exceptions were described in a study by (Wilhem et al. 2011), with a higher number of female Boxers and male Golden Retrievers in the studied population.

In the current study the Shih-tzu breed had the highest number of cases (51.7\%), further indicating the predisposition of this breed for CAD already documented by (Mueller 2003). Similar studies have demonstrated predisposition for CAD in a variety of breeds (Griffin \& Deboer 2001, White 2003, Gross et al. 2005). In 28 atopic dogs, Vandresen (2014) found $75 \%$ came from pure breed and 25\% from mixed-breed animals, while in a study in the North of Paraná, $40 \%$ of the dogs with CAD were of the Lhasa apso breed (Cardoso et al. 2011).

Picco et al. (2008) proposed that the regional popularity of some breeds or the different genetic backgrounds in different geographical areas could affect the predominance of CAD in some breeds. Marsella \& Souza (2001) and Favrot (2009) support the thesis that breed predisposition may vary depending on geographical location and regional variations. The influence of the different ways in which different breeds are housed or managed is also suggested (Wilhem et al.2011), which could form part of any future study to assess whether breed predisposition occurs or not. However, according to Willemse (1983), the most affected breeds are Lhasa apsos, Shih-tzus, Dalmatians, Pugs, Golden retrievers, Labradors, Cocker spaniels and Poodles, corroborating the result of this study where Shih-tzus (51.7\%) and Poodles (28.3\%) had the highest numbers of affected animals.

\section{CONCLUSIONS}

The results of the present study indicated that canine atopic dermatitis is the most frequently diagnosed in the HOVETUFRA Dermatology Department, that it is most prevalent in females and in the Shih-tzu breed, and that this may reflect a regional aspect of this dermatopathy.

The available knowledge concerning canine atopic dermatitis (CAD) epidemiology is limited, and the study in question has shown the need for both more research on the prevalence of canine atopic dermatitis, and improved characterization of the population of atopic dogs in the region, so that it becomes possible to obtain a reliable epidemiological profile regionally.

Conflict of interest statement.- The authors declare that they have no conflict of interest. 


\section{REFERENCES}

Alves B.H., Viana J.A., Leira M.H., Rodrigues N.P.A., Pristo A.L.P., Maia L.S., Silva S.M.V., Marinho K.A.O., Pereira M.B. \& Bertodo J.B. 2018. Dermatite atópica canina: estudo de caso. PubVet 12(8):1-6. <https://dx.doi.org/10.31533/ pubvet.v12n8a154.1-6>

Amarante C.F., Ramadinha R.R. \& Pereira M.J.S. 2015. Atopic dermatitis: a restrospective study of associated factors in a dermopathic canine population. Rev. Bras. Med. Vet. 37(Supl.1):13-17.

Barboza G., Villalobos A., Fernández G., Soto B.J., Ramírez R. \& García G. 2001. Dermatitis alérgica en caninos: estudio clínico dermatológico en 54 perros realizado en la Policlínica Veterinaria de la Universidad de Zulia. Revta Cient. Facul. Ciênc. Vet. 11(4):329-336.

Beteta G. 2016. Frecuencia relativa de dermatitis canina en tres clínicas veterinarias del distrito de Magdalena del Mar. Master's Thesis, Universidade Ricardo Palma, Lima, Perú.

Bizikova P., Santoro D., Marsella R., Nuttall T., Eisenschenk M.N.C. \& PucheuHaston C.M. 2015. Review: clinical and histological manifestations of canine atopic dermatitis. Vet. Dermatol. 26(2):79-e24. <https://dx.doi. org/10.1111/vde.12196><PMid:25676252>

Borracini L., Molinas J. \& Pirles M. 2018. Prevalencia de sensibilización a alérgenos ambientales en caninos con dermatitis atópica de la ciudad de Rosario, Argentina. REDVET, Revta Electrôn. Vet. 19(3).

Cardoso M.J.L., Machado L.H.A., Melussi M., Zamarian T.P., Carnielli C.M. \& Júnior Ferreira J.C.M. 2011. Dermatopatias em cães: revisão de 257 casos. Arch. Vet. Sci. 16(2):66-74. <https://dx.doi.org/10.5380/avs.v16i2.18482>

Favrot C. 2009. Clinical signs and diagnosis of canine atopic dermatitis. Eur. J. Compan. Anim. Pract. 19:219-222. <https://dx.doi.org/10.5167/ uzh-116541>

Favrot C., Steffan J., Seewald W. \& Picco F. 2010. A prospective study on the clinical features of chronic canine atopic dermatites and its diagnosis. Vet Dermatol. 21(1):23-31. <https://dx.doi.org/10.1111/j.13653164.2009.00758.x.> <PMid:20187911>

Gonzalez M.E., Schaffer J.V., Orlow S.J., Gao Z., Li H., Alekseyenko A.V. \& Blaser M.J. 2016. Cutaneous microbiome effects of fluticasone propionate cream and adjunctive bleach baths in childhood atopic dermatitis. J. Am. Acad. Dermatol. 75(3):481-493. <https://dx.doi.org/10.1016/j.jaad.2016.04.066> <PMid:27543211>

Griffin C.E. \& Deboer D.J. 2001. The acvd task force on canine atopic dermatitis (XIV): clinical manifestations of canine atopic dermatitis. Vet. Immunol. Immunopathol. 81(3/4):255-269. <https://dx.doi.org/10.1016/s01652427(01)00346-4> <PMid:11553388>

Gross T.L., Ihrke P.J., Walder E. \& Veren K. 2005. Doenças de Pele do Cão e do Gato: diagnóstico clínico e histopatológico. 2nd ed. Roca, Rio de Janeiro, p.200-206.

Hensel P., Santoro D., Favrot C., Hill P. \& Griffin C. 2015. Canine atopic dermatitis: detailed guidelines for diagnosis and allergen identification. BMC Vet. Res. 11:196.<https://dx.doi.org/10.1186/s12917-015-0515-5> <PMid:26260508>

Hill P.B., Lo A., Eden C.A.N., Huntley S., Morey V., Ramsey S., Ricardson C. Smithy D.J., Sutton C., Taylor M.D., Thorpe E., Tidmarsh R. \& Williams V. 2006. Survey of the prevalence, diagnosis and treatment of dermatological conditions in small animals in general practice. BMJ Vet. Rec. 158(16):533539. <https://dx.doi.org/10.1136/vr.158.16.533><PMid:16632525>

Hillier A. \& Griffin C.E. 2001. The ACVD task force on canine atopic dermatitis (I): incidence and prevalence. Vet. Immunol. Immunopathol. 81(3/4):147-151. <https://dx.doi.org/10.1016/S0165-2427(01)00296-3><PMid:11553375>
Jaeger K., Linek M., Power H.T., Bettenay S.V., Zabe S., Rosuchuk R.A. \& Mueller R.S. 2010. Breed and site predispositions of dogs with atopic dermatitis: a comparison of five locations in three continents. Vet. Dermatol. 21(1):118-122. <https://dx.doi.org/10.1111/j.1365-3164.2009.00845.x> <PMid:20187918>

Machado M.L.S., Appel C.E. \& Ferreiro L. 2004. Dermatófitos e leveduras isolados da pele de cães com dermatopatias diversas. Acta Scient. Vet. 32(3):225-232. <https://dx.doi.org/10.22456/1679-9216.16901>

Marcelo M. 2005. Dermatitis canina en el distrito de San Borja. Master's Thesis, Universidade Alas Peruanas, Lima, Perú.

Marsella R. \& Souza C.A. 2001. The ACVD task force on canine atopic dermatitis (XIII): threshold phenomenon and summation of effects. Vet. Immunol. Immunopathol. 81(3/4):251-254. <https://dx.doi.org/10.1016/S01652427(01)00303-8><PMid:11553387>

Medeiros V.B. 2017. Dermatite atópica canina. J. Surg. Clin. Res. 8(1):106-117. <https://dx.doi.org/10.20398/jscr.v8i1.13044>

Mueller R.S. 2003. Dermatologia para Clínicos de Pequenos Animais. Roca, São Paulo, p.159.

Neto A.S. 2012. Estudo da eficácia e segurança da ciclosporina no controle da dermatite atópica em cães. Master's Thesis, Pontifícia Universidade Católica do Paraná, São José dos Pinhais, PR. 116p.

Picco F., Zini E., Nett C.S., Naegeli C., Bigler B., Rüfenacht S., Roosje P., Gutzwiller M.E.R., Wilhelm S., Pfister J., Meng E. \& Favrot C. 2008. A prospective study on canine atopic dermatitis and food-induced allergic dermatitis in Switzerland. Vet. Dermatol. 19(3):150-155.<https://dx.doi. org/10.1111/j.1365-3164.2008.00669.x><PMid:18477331>

Scott D.W. \& Paradis M. 1990. A survey of canine and feline skin disorders seen in a university practice: Small Animal Clinic, University of Montréal, Saint-Hyacinthe, Québec (1987-1988). Can. Vet. J. 31(12):830-835. <PMid:17423707>

Scott D.W., Miller Jr W.H. \& Griffin C.E. 2013. Skin immune system and allergic skin diseases, p.543-666. In: (Eds), Small Animal Dermatology. 7th ed. Elsevier, Philadelphia.

Sischo W.M., Ihrke P.J. \& Franti C.E. 1989. Regional distribution of ten common skin diseases in dogs. J. Am. Vet. Med. Assoc. 195(6):752-756. $<$ PMid:2676928>

Souza T.M., Fighera R.A., Schmidt C., Réquia A.H., Brum J.S., Martins T.B. \& Barros C.S.L. 2009. Prevalência das dermatopatias não-tumorais em cães do município de Santa Maria, Rio Grande do Sul (2005-2008). Pesq. Vet. Bras. 29(2):157-162.<https://dx.doi.org/10.1590/S0100-736X2009000200013>

Vandresen G. 2014. Eficácia da ração de soja hidrolisada e da comida caseira com proteína original no controle da dermatite atópica em cães. Master's Thesis, Escola de Ciências Agrárias e Medicina Veterinária, Pontifícia Universidade Católica do Paraná, São José dos Pinhais. 76p.

White P.D. 2003. Atopia, p.372-380. In: Bichard S.J. \& Sherding R.G. (Eds), Manual Sauders Clínica de Pequenos Animais. 2를 ed. Roca, São Paulo.

Wilhem S., Kovalik M. \& Favrot C. 2011. Breed-associated phenotypes in canine atopic dermatitis. Vet. Dermatol. 22(2):143-149. <https://dx.doi. org/10.1111/j.1365-3164.2010.00925.x><PMid:20887404>

Willemse T. 1983. Investigations of the symptomatology and the significance of immediate skin test reactivity in canine atopic dermatitis. Res. Vet. Sci. 34(3):261-265. <PMid:6878876>

Zanon J.P., Gomes L.A., Cury G.M.M., Teles T.C. \& Bicalho A.P.C.V. 2008. Dermatite atópica canina. Semina, Ciênc. Agrárias 29(4):905-920. <https://dx.doi. org/10.5433/1679-0359.2008v29n4p905> 